University of Nebraska - Lincoln

DigitalCommons@University of Nebraska - Lincoln

Faculty Publications -- Department of English

English, Department of

Winter 2013

Networked Manufacture in Charlotte Brontë's Shirley

Peter J. Capuano

University of Nebraska-Lincoln, pcapuano2@unl.edu

Follow this and additional works at: https://digitalcommons.unl.edu/englishfacpubs

Capuano, Peter J., "Networked Manufacture in Charlotte Brontë's Shirley" (2013). Faculty Publications -Department of English. 134.

https://digitalcommons.unl.edu/englishfacpubs/134

This Article is brought to you for free and open access by the English, Department of at DigitalCommons@University of Nebraska - Lincoln. It has been accepted for inclusion in Faculty Publications -- Department of English by an authorized administrator of DigitalCommons@University of Nebraska - Lincoln. 


\title{
Networked Manufacture in Charlotte Brontë's Shirley
}

\author{
Peter J. Capuano
}

$\mathrm{F}$ or going on thirty years now, criticism of Charlotte Brontë's Shirley (1849) has hinged on tropes of displacement. The novel's 1849 publication date and its backdated subject matter (the 1811-12 Luddite rebellions) prompted Terry Eagleton to claim that "Chartism is the unspoken subject of Shirley" (45). Eagleton's sense that workers appear only in the text as "freaks or disembodied roars" allows him to make the compelling argument that Brontë substitutes subversive Chartism for explicit Luddism (50). Similarly, feminist critics have built on tropes of displacement by calling attention to the thematic connections Brontë makes between the plights of male woolen workers and middle-class female homemakers. Sandra Gilbert and Susan Gubar, and more recently Anna Silver and Beth Torgerson, have argued that starvation and hunger link the women of the novel to its unemployed workers. ${ }^{1}$ The staying power of these displacement-based interpretations no doubt owes much to Catherine Gallagher's pioneering book The Industrial Reformation of English Fiction, which asserts that the "industrial conflict in Shirley is little more than a historical setting and does not exert any strong pressure on the form" (xi n1).

This paper begins by arguing that we really should pay attention to the industrial element in Shirley, and not only because Charlotte Brontë thought of it as an industrial novel. ${ }^{2}$ I am not alone in making such an ar-

\footnotetext{
Abstract: This paper confronts many years of displacement-based readings of Charlotte Brontë's Shirley (1849) with a historicized "surface reading" that connects the manual labor of two very distinct constituencies in the novel: hardened Luddite machine breakers and dispossessed middle-class women. A surface-level line of inquiry into manufactured objects reveals an inverted network from the mill to the parlor; the redundancy of human hands caused by mechanization in the mill is concurrent with a surplus of female handiwork in the novel's middle-class homes. I argue that this inversion makes sense if we situate the novel in its 1811-12 setting - the unique historical moment when the term "manufacture" began to accrue paradoxically opposed meanings. Brontë's oscillation between mechanized and manual forms of manufacture in Shirley marks the early boundaries of what would eventually become the rigidly defined separate spheres of mid-century Victorian life.
} 


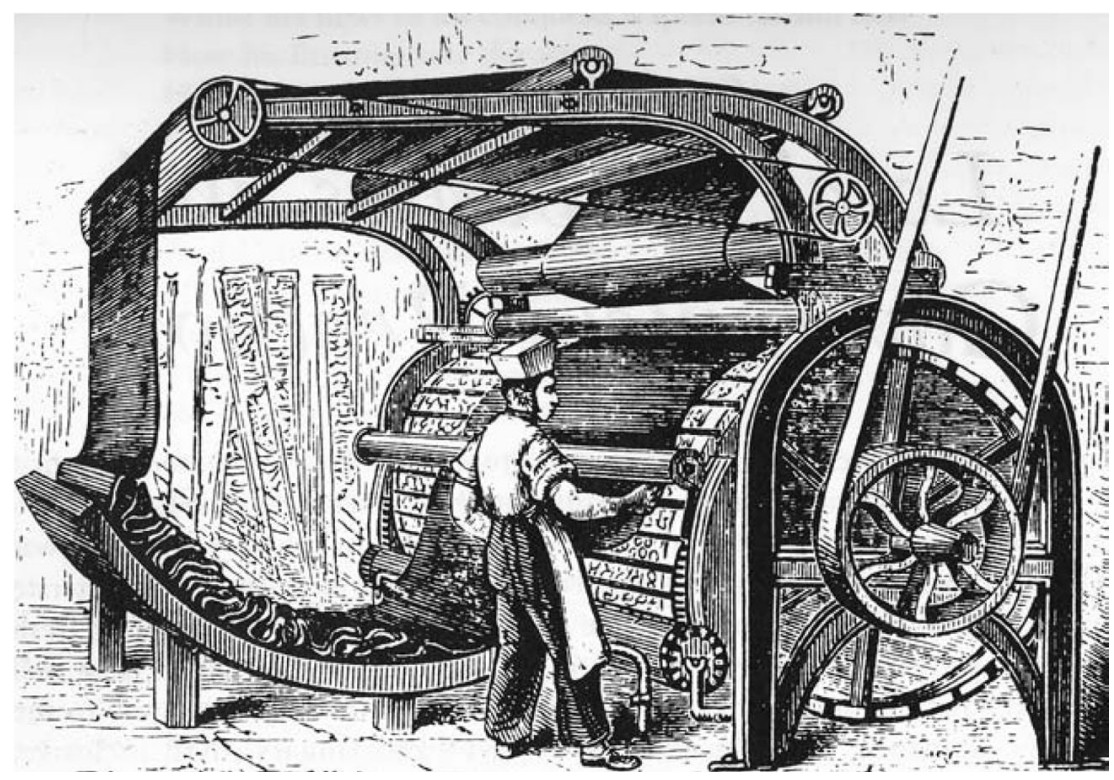

Figure 1. A gig-mill, from The Luddite Rebellion by Brian Bailey (New York: New York UP, 1998): 34. Reprinted by permission of New York University Press.

gument. Sally Shuttleworth has shown that the analogy between the unemployed worker and the so-called surplus middle-class woman is central to the structural organization of the novel (183). But I want to make a more direct and more historicized claim about how Brontë's treatment of manufacturing in the novel connects or networks two very different constituencies: hardened Luddite machine breakers and dispossessed middle-class women for whom professional opportunities outside the home were extremely limited. ${ }^{3}$

The interpretive method I use follows an emerging kind of "surface reading" to illuminate obvious textual features that critics have overlooked (Best and Marcus 7). This methodology seeks to draw meaning from what is visible on the text's surface, meaning that symptomatic (suspicious) reading has rendered ironically invisible. In the case of Shirley, a surface-level line of inquiry into manufactured objects reveals an inverted network from the mill to the parlor; that is, the redundancy of human hands caused by mechanization in the mill is concurrent with a surplus of female handiwork in the novel's middleclass homes. I will argue that this inversion makes sense if we think about Brontë's novel in terms of its original historical context. Shirley's 1811-12 setting situates the novel's action at the unique historical moment when manufacture began to accrue paradoxically opposing meanings. As Andrew Ure noted 


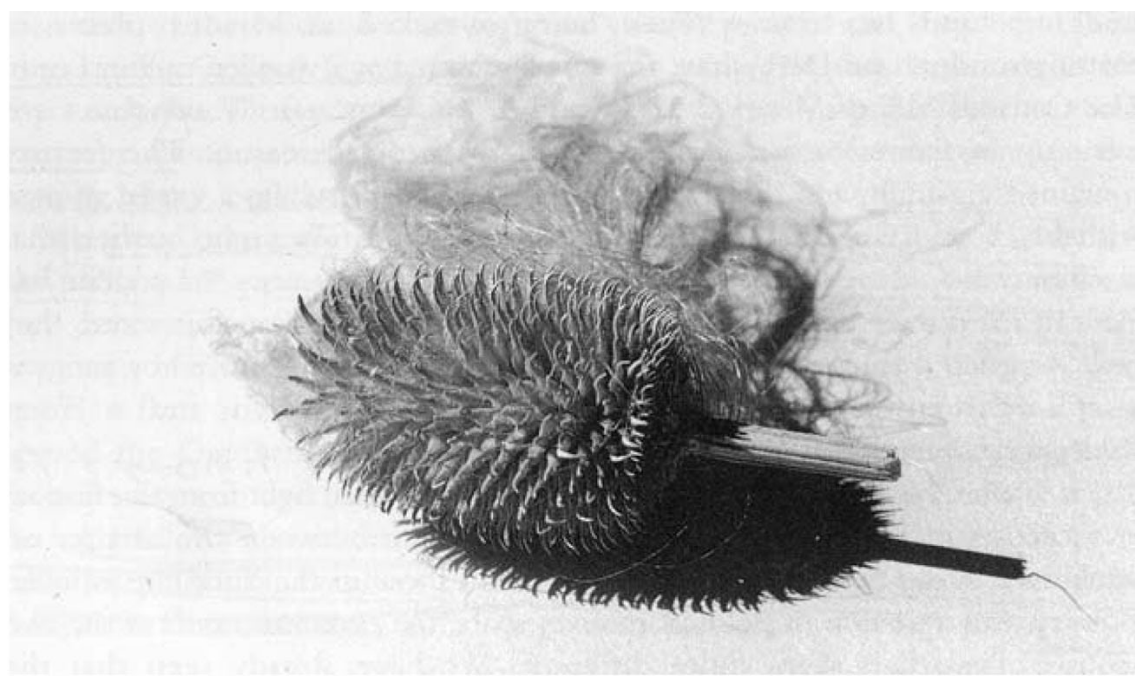

Figure 2. The head of the teazel plant, Dipsacus fullonem, from The Luddite Rebellion by Brian Bailey (New York: New York UP, 1998): 26. Reprinted by permission of New York University Press.

in Philosophy of Manufactures (1835), the word "manufacture" could now "signify the reverse of its intrinsic meaning ... denot[ing] every extensive product of art, which is made by machinery, with little or no aid of the human hand" (1). I focus on Brontë's oscillation between the intrinsic and denotative meanings of manufacture in order to trace the relationship between machine work and "hand-labour" in the text (155).

Where the majority of critics see Shirley's "virtual abandonment of the industrial issue" (Bodenheimer 42), I see its constant reiteration in Brontë's interpretation of the dual meanings of manufacture. The rapid development and incorporation of teazeling machines and mechanical shears, the kind of machinery en route to Robert Moore's mill at the outset of Shirley (see Figure 1), fostered a revolution not only in working methods, but also a complete disruption of a way of life for the croppers who had been the highest paid of all woolen workers for centuries (Bailey 26). Indeed, by eliminating the labor required to raise the nap of the wool by hand with the spiky bracts of the teazel plant (Figure 2) and crop it with manual shears (Figure 3), the process of finishing cloth was reduced from over a week to less than a single day. We see the most obvious effect of these new production methods in the unforced unemployment of male workers like Joe Scott and William Farren, who plead with Robert Moore to implement machinery "more slowly" (Brontë 157, 178). 


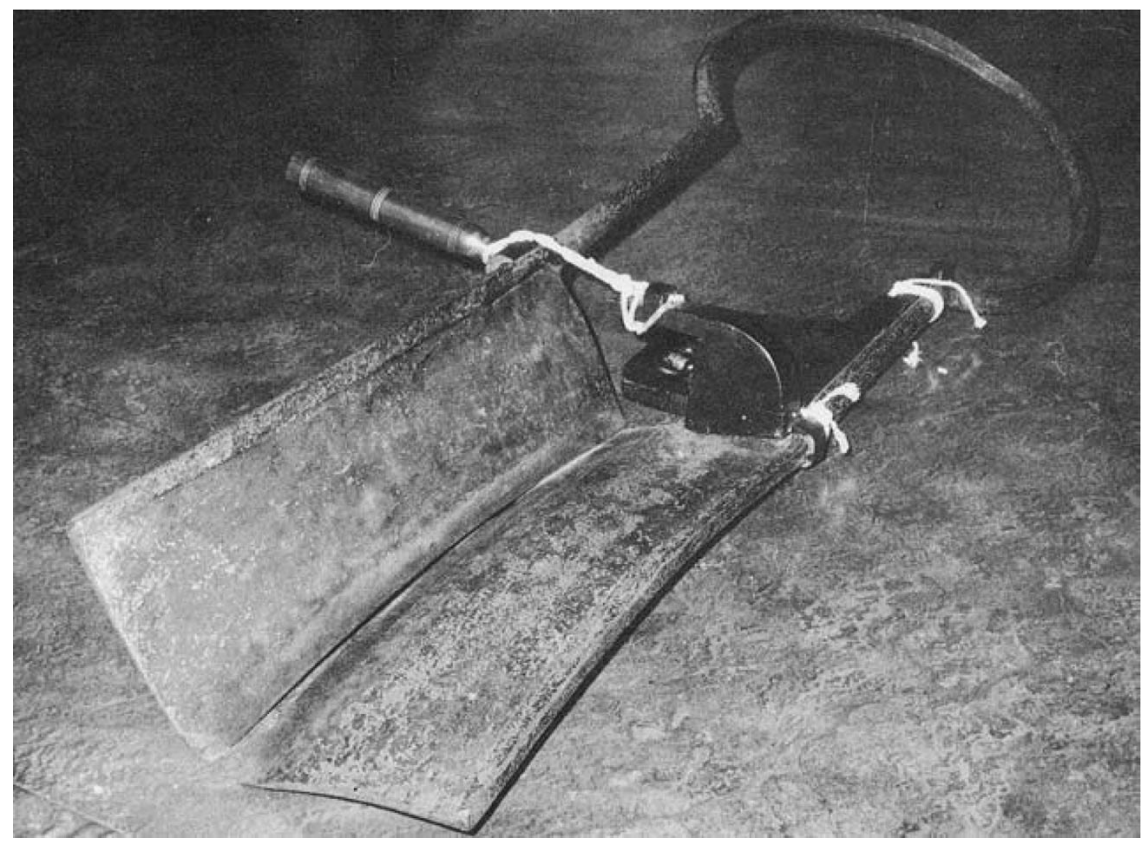

Figure 3. Hand cropping shears, from The Luddite Rebellion by Brian Bailey (New York: New York UP, 1998): 27. Reprinted by permission of New York University Press.

The relationship in the novel between the loss of manual labor among working men and the surge in handiwork among middle-class women occurs also in the wider cultural discourse of the period. While pro-industrialists like Ure were promoting self-acting machines that manufactured with "mechanical fingers and arms" (15), middle-class magazines such as Jane Louden's Ladies' Companion were celebrating the fact that "never were fingers more actively engaged [in handicraft] than those of the rising female generation" ("The Work Basket"). Scholars of Victorian materialist practices have sought to account for this phenomenon by considering the ways in which handicrafts provided domestic compensation for the loss of manual authenticity in the industrial realm. In The Victorian Parlour, for example, Thad Logan notes that "there seems to have been a compensatory emphasis on the amateur practices of ornamental sewing and handcrafts" as industrial capitalism began to dominate production (164). Talia Schaffer goes a bit further, claiming in Novel Craft that "the craft paradigm" represents "an ideal solution" (4), "a creative outlet that allowed middle-class women to articulate their relation 
to the industrial economy in a satisfyingly complex way" (5-6). This reasoning certainly suffices for the novels Schaffer analyzes and, we might say, for the overwhelming majority of Victorian prose related to female craftwork. Yet it does not explain why Charlotte Brontë treats handicrafts so differently. In Shirley, needlework appears as a bitter, dispiriting, and deeply depressing activity that is representative of a more generalized feminine futility because it occurs alongside the robust middle-class male enterprise of industrial manufacture. ${ }^{4}$

Figuring out why this is the case requires us to focus more narrowly on the historical model that Brontë chooses to employ for this text. The Luddite rebellions mark the first and most distinct of many radical changes to England's process of industrialization and, as such, they also mark an early stage of what would become, by the time Brontë composed the novel in 1848-49, the rigidly gendered spheres of middle-class life. Considered from this vantage point, Shirley chronicles the ways in which new modes of production influence new modes of relation within the middle-class household.

Leonore Davidoff and Catherine Hall have shown that during the late eighteenth and early nineteenth centuries middle-class women were socially and spatially separated from the site of work for the first time in history. Previous views of work tended to stress an inclusive attitude toward labor; women as well as men were seen as important to the nation's economic industriousness. However, a convergence of several social and economic factors at the turn of the nineteenth century led to a reconceptualization of women's work. Thomas Malthus's Essay on the Principle of Population (1798) became one of the earliest articulations of separate-sphere ideology by emphasizing woman's biological rather than her economic functions. Developments in machine technology in the first decade of the nineteenth century (especially in Yorkshire) and the attendant movement of work toward large-scale factory settings solidified the definition of labor as offlimits to middle-class women (Valenze 84).

In Shirley, Brontë wastes no time in dramatizing the stark separation of these newly gendered spheres. The opening pages include a dinner at the Gale household, where the local curates and parsons meet to air their usual "clerical quarrels" (44), but also to discuss the delivery of mechanized shearing frames to Robert Moore's mill (44-47). The scene culminates with the clergymen gathering their pistols to meet at Hollow's End Mill in case the machines are met with any trouble. During the dinner there is a particularly hostile interaction between Mr. Malone, 
the curate of Briarfield, and Mrs. Gale, the middle-class wife who hosts the dinner. Mr. Malone's arrogant and urgent request for more bread prompts the following exchange: "Mrs. Gale offered the loaf. 'Cut it, woman,' said her guest; and the 'woman' cut it accordingly. Had she followed her inclinations, she would have cut the parson also; her Yorkshire soul revolted absolutely from his manner of command" (42). I agree with Igor Webb that the quotation marks around "woman" indicate that Brontë intends to draw our attention to the falsity of the distinctions Malone makes between the sexes (143). More specifically, Brontë's alignment of the clergy with Moore's machinery and Mrs. Gale's Yorkshire inclination to "revolt" underscores the relative newness of the distinction between male and female roles in this burgeoning industrial society. We see throughout the text this pattern of distinguishing between the gendered spheres, whether in Reverend Helstone's command for Caroline to "stick to the needle-learn shirt making and gown-making, and pie-crust baking" (122) or Robert Moore's condescending comparison of his injuries to the way Caroline "might scratch [her] finger with a needle in sewing" (350).

As these scenarios indicate, middle-class women like Caroline Helstone increasingly were expected to remain at a literal and symbolic distance from the new world of mechanized production. Doing so, in fact, became the most precise marker of their new identity. Brontë brilliantly reinforces this point by arranging to have Caroline's first needlework session occur during the same afternoon that Moore's second shipment of labor-saving machinery is delivered to the mill:

The afternoon was devoted to sewing. [Hortense], like most Belgian ladies, was specially skillful with her needle. She by no means thought it a waste of time to devote unnumbered hours to fine embroidery, sightdestroying lacework, marvelous netting and knitting, and, above all, to the most elaborate stocking-mending. She would give a day to the mending of two holes in a stocking at anytime. . . . It was another of Caroline's troubles to be condemned to learn this foreign style of darning, which was done stitch by stitch so exactly to imitate the fabric of the stocking itself. . . . All afternoon the two ladies sat and sewed, till the eyes and fingers, and even the spirits of one of them were weary. (107-08)

Brontë follows up this tiresome description of handiwork with a seemingly innocuous scene in which the family reads Coriolanus. Putting aside 
for the moment the connection between Robert's treatment of his mill workers and Coriolanus's treatment of his countrymen, it is important to note that Hortense uses this moment to continue Caroline's education in the middle-class ideology of separate spheres. "When the gentleman of a family reads," Hortense declares matter-of-factly, "the ladies should always sew" (115).

Once Caroline sews so much and so often that she can do so without thinking, her hatred of its tediousness quickly overwhelms her. Charitable sewing for the missionary and Jew baskets is particularly difficult for Caroline because of the work's utter disconnection from the laws of authentic, real-world trade. Caroline yearns to help out in the mill, even going so far as to "wish nature had made her a boy instead of a girl, that she might . . . be [Robert's] clerk, and sit with him in the counting house" (104). Instead, Caroline must settle for making domestic objects that are "quite useless" to the middle-class men who are obligated to buy them at "four or five hundred per cent above cost price" (134). As Schaffer points out, the violations of ordinary business practice that originate in the missionary baskets "confirmed that women were merely 'playing,' in a separate realm not bound by the laws of trade" (12).

Fixating on this futility prompts Caroline to consider older models of female work where women actively participated in the economic wellbeing of their families. During one of her most tedious sewing sessions Caroline recognizes the artificiality of the separation between the public and private spheres. Brontë highlights this artificiality by introducing Solomon's "virtuous woman" from Proverbs. Caroline recounts chapter 31 of Proverbs nearly word for word as she ponders the woman who participated in both public and private spheres, who "had something more to do than spin and give out portions: she was a manufacturershe made fine linen and sold it: she was an agriculturalist-she bought estates and planted vineyards. That woman was a manager" (378). In the character of Shirley Keeldar, owner of the land upon which Moore's mill sits, Brontë updates Caroline's model woman from the distant biblical past to the immediate present of 1812. We learn that Shirley "is lax of her needle" (372) and that "she never sews" because she must tend to the daily operations of her estate (373). In the few times that Shirley does sit down to sew, the narrator tells us that "her thimble is scarcely fitted on, her needle scarce threaded" (372) before she is called away to tend to animals "with her own hand" and to decide "whole agricultural matter[s] on the spot" (373). 
Eventually, Brontë establishes a thematic relationship between the powerlessness of the croppers in an unbridled capitalist economy and the powerlessness of middle-class women in a patriarchal hierarchy. It's no coincidence that this relationship depends heavily on the materiality of hands. In a Lamarckian context, the supersession of the cropmen's hands by machines parallels Caroline's and Shirley's sicknesses, both of which are registered principally in the diminishment of their hands. ${ }^{5}$ The narrator remarks that it gives "pain to see" the "attenuation" of Caroline's wasted hand (403), while Henry Sympson claims that Shirley's death is near because "her hands are growing quite thin" (471). The overemployment of middle-class female hands and the underemployment of Luddite hands both reflect a rapidly changing economic reality that only sharpens the lines delineating the separate spheres for each gender. The technological changes that prove so destructive to the Yorkshire croppers allow lower-class women to perform the work previously accomplished by skilled tradesmen. As a result, middle-class women become further defined by their distance from millwork. So great does this distance become even in 1812 that it takes a partial hallucination on Moore's part even to imagine Caroline on the factory floor amid the "buxom lasses" who toil there (257). Caroline wishes "fifty times a-day" for "absorbing" work to "fill [her] head and hands" (235) but is met with a new social reality that, like Reverend Helstone, considers "everything but sewing and cooking above women's comprehension" (118). There's an ironic historical similarity in the Luddite Moses Barraclough's desire for the time "when hand-labour were encouraged and respected" (155) and Caroline's desire for work beyond that which "only keeps [her] hands busy" (115).

Brontë solidifies this connection between Luddite men and middle-class women by tracing the suffering caused by mechanization in the industrial sphere to a particular form of suffering in the domestic sphere. Smarting from her rejection by Robert Moore and without recourse to the kind of productive work from which Shirley benefits, Caroline doubles down on her sewing. The text constantly rehearses the repetitiveness of Caroline's efforts to sew her way through the "solitude, the sadness, the nightmare of her life" (381). Her servant, Fanny, notices that Caroline is "always in the same place, always bent industriously over a piece of work" (191). The narrator remarks that instead of finding Caroline "in the blooming garden of an English home," she appears "sitting alone in the alcove, - her task of work on her knee, her fingers assiduously plying the needle, her eyes following and regulating their movements, her 
brain working restlessly" (380). With these images of Caroline-working unceasingly, in physical discomfort, cramped, bent, and kept indoorsBrontë aligns middle-class domestic work with lowerclass mill workers and seamstresses.

T. J. Edelstein has shown the ways in which the overnight success of Thomas Hood's "The Song of the Shirt" (1843) and the popularity of Richard Redgrave's paintings codified the subject of the needlewoman in the nineteenth-century imagination. Shirley's readers would have been familiar with lines from Hood's poem: "A little weeping would ease my heart, / But in their briny bed / My tears must stop, for every drop / Hinders needle and thread" (70-74). Brontë describes Caroline's suffering in strikingly similar language:

She plied her needle continuously, ceaselessly; . . . her head labored to frame projects as diligently as her hands to plait and stitch the thin texture of the muslin summer dress. . . Now and then, while thus doubly occupied, a tear would fill her eyes and fall on her busy hands; but this sign of emotion ... was quickly effaced: the sharp pang past, the dimness cleared from her vision; she would re-thread her needle, re-arrange tuck and trimming, and work on. (244)

The rhetoric of Caroline's hands moving "continuously, ceaselessly" to keep pace with the work echoes Ure's encouragement for workers "to identify themselves with the unvarying regularity of the complex automaton" (14-15). This is exactly how many middle-class females in Shirley view themselves. In the Yorke household, for instance, Jessie Yorke claims that her older sister Rose is an "aut-aut-I have forgotten the name, but it means machine in the shape of a human being" (383).

As I conclude, I want to return to a surface-level connection that has remained unnoticed in Shirley criticism so far. If, as I've tried to demonstrate, a direct manual network exists between the Yorkshire croppers and the middle-class women, then we should be able to identify something analogous to the male Luddite rebellion in the female sphere, something beyond Mrs. Gale's repressed desire to revolt. We certainly don't see this in Caroline's actions: she pleads for "scope and work" but marries Moore and quiescently returns to the sewing she had so adamantly repudiated (379). Perhaps more surprisingly, we learn that Shirley Keeldar, upon her marriage to Louis Moore, is no longer a "Thalestris from the fields, but a quiet domestic character from the fireside" who routinely plies her needle (473). The patriarchal reach becomes so pervasive in Shir- 
ley that we see it even in Fieldhead's sky, where a "cloud like a man's hand ar[ises] in the west" and "gusts from the same quarter dr[ive] it on and spread it wide" (419).

Despite this, however, there is a female rebellion waged against Robert Moore just after the revolt at his mill. Rehabilitating at the Yorkes' from a Luddite gunshot wound, Moore is nursed not by Mrs. Yorke or any of the Yorke girls but by a previously unintroduced Mrs. Horsfall. I think this is where Brontë is having some fun with us. Moore falls from his horse when he's shot; moreover, William Horsfall was a real historical figure who owned the Ottiwells Mill at Marsden where proto-Luddite rebellions first occurred in 1803. Brontë's Mrs. Horsfall, however, has all the physical characteristics of one of the brutally strong Yorkshire croppers who operated the fifty-pound shears that Moore replaced with machines. The narrator describes her as a "giantess" nurse (526) with hands so large that "she could hold half a dozen hands like yours in her one palm" (532). According to the young Martin Yorke who listens from outside the sickroom, Moore "hate[s] the sight of her rough bulk, and dread[s] the contact of her hands" (526) because "she knocks him terribly about in that chamber" for the entire month of November (532). Her rough bearing, along with her smoking and gin drinking, align Mrs. Horsfall quite directly with the unemployed laborers toward whom Moore acts so callously for most of the novel. The coup de grâce is that Mrs. Horsfall starves Moore during his captive rehabilitation at the appropriately named Yorke estate of Briarmains. By "eat[ing] most of what goes up on the tray to Mr. Moore," Mrs. Horsfall forces Moore to experience what his unemployed cropmen endured in the months after his mechanical shearing frames arrived in Hollow's mill (532).

Key here is how closely Brontë hews to the historical model that she had in mind when she sent for old editions of the Leeds Mercury and the Leeds Intelligencer during her composition of the text. It's crucial that Mrs. Horsfall's rebellion, like the Luddite rebellions of 1811 and 1812, is temporary. Moore eventually leaves Mrs. Horsfall's care, marries Caroline, and returns to Briarfield to continue the mechanization of the Hollow - a set of events that confirms the irreversible losses sustained by textile tradesmen and middle-class women. From her vantage point in 1849, Charlotte Brontë recognized the causal relationship between mechanized manufacture and the hardening of the boundaries between the separate spheres of Victorian social life, yet she offers no moral for the "judicious reader putting on his spectacles 
to look for [one]" (599). Shirley simply recounts a fictional history of how it came to be this way.

\section{University of Nebraska-Lincoln}

\section{Notes}

1. See Gilbert and Gubar 372-98; Silver 81-115; Torgerson 39-57. Torgerson focuses on cholera in particular.

2. In a letter to her publisher in February 1849, Brontë wrote that "in reading Mary Barton (a clever though painful tale) I was a little dismayed to find myself in some measure anticipated in both subject and incident" (qtd. in Hook 9).

3. I agree with Susan Zlotnick that Brontë links middle-class women to workingclass men through the common affliction of unemployment. Zlotnick, however, sees this analogy breaking down because "the interests of the male Luddites and those of the novel's women are not identical." My contention is that the loss of "a centuries-old way of life" (Zlotnick 94), though not identical, applies to both workingclass men and middle-class women in the first decade of the nineteenth century.

4. As Helena Michie has noted, sewing takes on a "sinister cast" in the lives of many fictionalized leisure-class heroines (43). Where Michie's analysis focuses on repressed feminine bodily urges, I am interested in the specifically material relationship between industrial and domestic manufacture.

5. Lamarck believed that the use or disuse of a bodily organ or appendage could increase or diminish its size. Such a process, he believed, could take place within a single generation.

\section{Works Cited}

Bailey, Brian. The Luddite Rebellion. New York: New York UP, 1998.

Best, Stephen, and Sharon Marcus. "Surface Reading: An Introduction." Representations 108.1 (2009): 1-21.

Bodenheimer, Rosemarie. The Politics of Story in Victorian Social Fiction. Ithaca: Cornell UP, 1988.

Brontë, Charlotte. Shirley. New York: Penguin, 1974.

Davidoff, Leonore, and Catherine Hall. Family Fortunes. London: Hutchinson, 1987.

Eagleton, Terry. Myths of Power. Rev. ed. New York: Palgrave, 2005.

Edelstein, T. J. "They Sang 'The Song of the Shirt': The Visual Iconology of the Seamstress." Victorian Studies 23.2 (1980): 183-210.

Gallagher, Catherine. The Industrial Reformation of English Fiction: Social Discourse and Narrative Form 1832-1867. Chicago: U of Chicago P, 1985.

Gilbert, Sandra, and Susan Gubar. The Madwoman in the Attic. 2nd ed. New Haven: Yale UP, 2000. 
Hood, Thomas. "The Song of the Shirt." The Broadview Anthology of English Literature. Ed. Joseph Black et al. Vol. 5. Peterborough: Broadview, 2006. 57-58.

Hook, Andrew, and Judith Hook. Introduction. Shirley. By Charlotte Brontë. New York: Penguin, 1974. 7-32.

Logan, Thad. The Victorian Parlour. Cambridge: Cambridge UP, 2001.

Malthus, Thomas. An Essay on the Principle of Population. Ed. Philip Appleman. New York: Norton, 1976.

Michie, Helena. The Flesh Made Word. Oxford: Oxford UP, 1987.

Schaffer, Talia. Novel Craft. Oxford: Oxford UP, 2011.

Shuttleworth, Sally. Charlotte Brontë and Victorian Psychology. Cambridge: Cambridge UP, 1996.

Silver, Anna. Victorian Literature and the Anorexic Body. Cambridge: Cambridge UP, 2002.

Torgerson, Beth. Reading the Brontë Body. New York: Palgrave, 2005.

Ure, Andrew. The Philosophy of Manufactures. London: H. G. Bohn, 1861.

Valenze, Deborah. The First Industrial Woman. Oxford: Oxford UP, 1995.

Webb, Igor. From Custom to Capital. Ithaca: Cornell UP, 1981.

“The Work Basket.” Ladies' Companion Dec. 1849: 4-5. Rpt. in Logan 168.

Zlotnick, Susan. Women, Writing, and the Industrial Revolution. Baltimore: Johns Hopkins UP, 1998. 